\title{
HUMAN RESOURCES IN LOGISTICS AND SUPPLY CHAINS: CURRENT STATE AND TRENDS
}

\author{
Milorad Kilibarda ${ }^{1}$, Vukašin Pajić ${ }^{2}$, Milan Andrejić ${ }^{3}$ \\ 1,2,3 University of Belgrade, Faculty of Transport and Traffic Engineering, Serbia
}

Received 12 March 2019; accepted 08 April 2019

\begin{abstract}
This paper presents the results of the research of human resources in logistics and supply chains. The analysis covered different researches in developed and developing countries. The needs and problems with labor shortage, required logistics competencies and skills, as well as problems and solutions related to employment and retention of the labor are considered in detail. The results of the research conducted by authors in the Serbian market are presented. Also results showed that there is a large fluctuation caused by salaries, inability to progress and lack of vision of the company. The research was carried out on a sample of 314 respondents of mainly highly trained logistics specialists in different positions and in different industries. The results of all researches have shown that there is an evident lack of logistics experts in all positions and in all countries and regions. The situation is similar in the Serbian market.
\end{abstract}

Keywords: human resources, logistics, supply chains, recruitment, retention.

\section{Introduction}

Logistics is a key factor in economic development, economic growth, spatial integration and market integration. It has a significant impact on economic performance in different industries and national economies. Unlike the past, today the importance of logistics and the need for its construction and development on a global, regional and local level is becoming more and more important. When discussing the development of logistics, it is mainly thought of logistics and transport infrastructure, harmonization of regulations and law, i.e. creating an economic environment and facilitating the undisturbed flow of goods, people and capital. However, the growing problem is the workforce, logistics competencies and skills. It is labor intensive activity and despite the high level of technological development, process mechanization, automation and robotization, the main resources are personnel and labor.

The construction and development of human resources is equally, if not more important than the construction of infrastructure. Researches carried out in recent years in many developing and developed countries has shown that companies have significant difficulties in hiring staff with the necessary skills and knowledge to manage logistics processes and supply chains. The results of the researches show that logistics staff at all levels from drivers, warehouse workers to the senior managers in the supply chain are missing. A similar situation exists in Serbia where problem of finding workers with certain qualifications and skills is often recognized.

${ }^{2}$ Corresponding author: v.pajic@sf.bg.ac.rs 
Generally, in the professional public, there is general consensus on the importance of human resources in logistics and supply chains (Fisher et al., 2010; Cottrill \& Rice Jr., 2012; Andrejic et al., 2013; Ellinger \& Ellinger, 2014; Kilibarda et al., 2016). In spite of this fact, this topic is not being explored and processed enough. For example, in scientific journals in the field of logistics and supply chains only 0,57 papers deal with this issue. Of this, $87 \%$ of the articles are related to the issue of logistics competencies (Hohenstein et al., 2014).

The above facts and general state of logistics staff were the main motives for researching and writing this paper. The main goal of the paper is to research and review the existing situation, and provide specific suggestions and guidelines for the development of human resources in logistics and supply chains. The results of the conducted research are presented through two parts. In the first part, a summary of the situation in the world is given with special emphasize on needs and shortage of the workforce and competencies as well as recruitment. The second part of the paper is related to the results of the research in Serbia. In the last section concluding remarks and future research directions are given.

\section{Current State and Trends of the Logistics Sector in the World}

An analysis of the current situation and trends in the world has been carried out on the basis of a large number of research results and papers published in recent years. One of the most important and most complete research was realized by the World Bank and its research partners from the Kühne Logistics University in Hamburg, Germany. This research deals with logistics skills and competencies at the global level.
The researchers dealt with challenges in recruitment and retention of the workforce in both developing and developed countries. Some of the most important results that researchers have come up with are presented in the following parts of the paper.

\subsection{Needs and Shortage of the Workforce}

In the last years, the need for qualified labor in logistics has grown considerably. This is the result of the growth of economic activities, the spatial dispersion of production and consumption, the expansion of companies on the international and global level, the increasingly complex and stringent demands in logistics and supply chains. It is estimated that labor demand in logistics in the world is growing at a rate of $10-12 \%$ per year. The results of research in different parts of the world show the shortages of the workforce with appropriate logistics competencies and skills. Shortage range from the lack of drivers to the problem of filling higher supply chain management positions. It is estimated that this problem will remain the same in the next five years. In developed countries, shortcomings relate to all levels of logistics profession, but are more present at lower levels. Developing countries are seriously confronted with a weak supply of skilled labor, although there is a high level of unemployment in these countries. The lack of staff with the skills necessary for the supervisor and higher logistics management positions is especially emphasized in these countries. The lack of specialized schools and faculties that would train professional labor has been noticed in developing countries. Researches indicate a significant gap between the significance and availability of the logistics staff with the appropriate skills needed to perform tasks on certain positions in the supply chain (figure 1). 


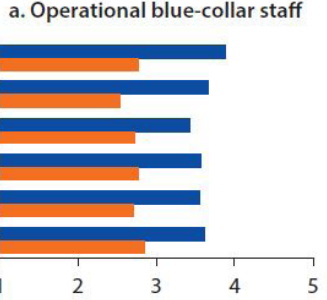

c. Logistics supervisors

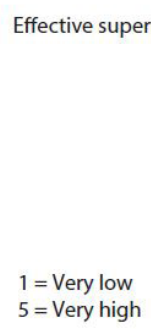

b. Administrative staff

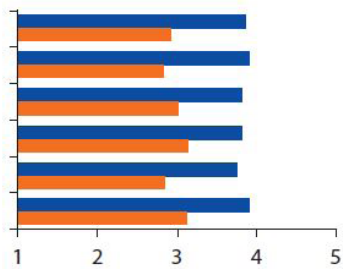

d. Logistics managers

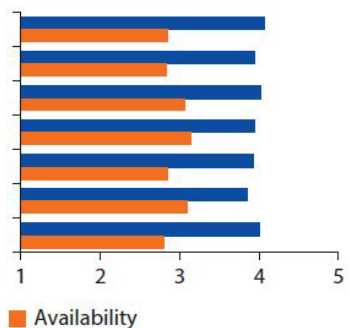

Fig. 1.

Gap Between Importance and Availability of Competences

Source: (McKinnon et al., 2017)

The significance of all logistics skills is a very highly graded (average grade 4 on scale $1-5)$, while the availability of staff with these skills is considerably worse (usually 2,8-2,9) (McKinnon et al., 2017).

It is considered that poor availability of staff with the necessary logistics skills is small for two key reasons. The first reason is that there are not enough staff on the labor market with appropriate skills and qualifications. Another reason is the lack of skills in the existing logistics workforce. Rapid technological development in logistics and supply chains requires new competencies that the existing labor does not possess. A large number of employees in logistics cannot follow technological innovations, great dynamics in the market, complex operating and work procedures.

There is an expert consensus on the reasons for the lack of staff with the necessary logistics competencies and skills. The potential for employment in the logistics sector is often limited by its relatively poor image. In most countries, the logistics sector suffers from low economic and social reputation and status in relation to other professions (McKinnon et al., 2017). This directly affects career planning where talents and potential managers choose other professions and give up on logistics. The salaries of employees in logistics are significantly lower in relation to some other professions, which places this sector in an inferior position when choosing a profession and employment. This particularly applies to workers on operational level. One of the reasons is definitely characteristics of the operational tasks in logistics. In many positions, these are very stressful and dynamic jobs with hard work and night shifts. Also, many logistics companies are located far from towns and places of residence in 
industrial areas or locations that are close to the highway, which directly affect travel time to and from work (Sheffi, 2013).

\subsection{Competencies of the Logistics Workforce}

Different researchers found what skills are crucial for managers in supply chain management. According to Harvey and Richey (2001) managers should have managerial and transformation-based skills. Richey et al., (2006) found that verbal IQ, achievementorientation and high adaptability are crucial for managers. Beside managers, all logistics employees must have skills associated with understanding various business fields, strategic decision-making, communication, leadership and IT in order to cope with daily tasks (Hoberg et al., 2014). Based on the results of the research, which was conducted in Poland based on the sample of 500 people it was found, that more than $50 \%$ of the respondents think that activities performed by logistics employees are crucial for enterprise. Only $6 \%$ thought they do not have crucial role. When asked about crucial employee's characteristics, respondents marked responsibility $(21,4 \%)$, creativity $(19,5 \%)$ and ability for team work $(17,4 \%)$ (Slusarczyk and Kot, 2011). Results of the research also showed crucial science domains, which are most frequently used at work and which should be the foundation of education. Those domains are associated with marketing, IT, HR management and foreign languages (Slusarczyk and Kot, 2011). Research conducted by Thai (2012), also had the goal to determine what skills logistics labor should have. Author found that the most important skills and knowledge are personal integrity, managing client relationships, problem-solving ability, cost control and ability to plan. The least important skills and knowledge according to this research are packaging, managing returned products and scrap disposal, international business regulations and knowing two or more languages. Poorly positioned and assessed knowing two or more languages is due to the fact that respondents were from Australia, where English is the native language. When asked about the most important skills, senior level respondents rated analyzing statistical data, marketing, HR management, strategic management, understanding economic principles, engineering logistics and ability to organize as the most important ones Thai (2012).

\subsection{Recruitment and Retention}

Key challenges which are HR facing in today's market are recruitment and retention of the labor. Firstly, companies cope with problem of recruiting employees where labor shortage exists. Beside salary, benefits and security, as the most important factor for recruitment was found to be transparent career path to senior management (McKinnon et al., 2017). One solution which can help with recruitment of the labor is investing in employer branding, which can be a decisive factor in choosing a company. This method is more effective when choosing top management, but gap still exists on entry-level. In order to solve this problem there are some solutions which can be adopted. Namely, companies can connect with student before their graduation, help them with their projects or even give scholarships, after which students would have to work for the company for a certain period. In today's market, where fluctuation is greater than ever, companies face problems associated with retention of labor. Problem of retention is maybe even bigger than recruitment, mainly because people are willing to change company for a better working conditions. Competition exists even between sectors (in the same company), 
not just between companies. As a consequence of this, logistics sector cannot compete with other sectors like sales, marketing or finance. For that reason, logistics sector must provide and emphasize other factors which are crucial for retention, other than salary. These factors are: number of working hours, working environment, job satisfaction, etc. (McKinnon et al., 2017). Beside recruitment and retention, according to World Bank study, keeping salaries and benefits competitive and succession planning are the two most challenging tasks for HR in logistics (when observing emerging regions). When observing developed regions, two most challenging tasks are developing leadership skills and keeping salaries and benefits competitive (McKinnon et al., 2017).

\section{Table 1}

Factors for Retention by Sector

\begin{tabular}{|c|c|c|}
\hline Factor for Retention & Supply Chain (\%) & Logistics Sector (\%) \\
\hline Terms and conditions (pay and working hours) & 45 & 34 \\
\hline Working environment & 20 & 18 \\
\hline Limited opportunities elsewhere & 19 & 23 \\
\hline Job satisfaction & 18 & 17 \\
\hline How staff are treated & 15 & 14 \\
\hline Job security & 14 & 11 \\
\hline Company reputation & 13 & 7 \\
\hline Training opportunities & 9 & 9 \\
\hline Family-run business & 5 & 42 \\
\hline Staff loyalty & 5 & \\
\hline Others & 16 & \\
\hline
\end{tabular}

Source: (McKinnon et al., 2017)

\section{Current state in Serbia}

Research on the state of human resources in the field of logistics and supply chains in the Serbian market was conducted according to the developed methodological procedure based on the survey research. A questionnaire had 20 basic questions, after which a target group of respondents was defined, comprised of logistics experts at various positions in the supply chain. The questionnaire consists of two parts. The first part is related to the characteristics of the sample, while the second part is related to the state and characteristics of human resources in logistics and supply chains. The questionnaire was first tested on a sample of 30 respondents and when its validity and credibility was confirmed, it was sent to the respondents via the web survey. The survey was conducted in the period from January to April 2019. A total of 370 completed questionnaires were collected. After selective analysis, responses that were not completely filled were excluded from further analysis which ended with 314 fully filled questionnaires. The collected data has been statistically processed and analyzed, and the most important results are presented below.

\subsection{Characteristics of the Sample}

The selected sample consists of highly trained logistics staff that work in different companies and in different positions. 
About $50 \%$ of the respondents are employed in international logistics and freight forwarding, while others work in distribution and domestic transport $(23 \%$ of respondents), production $(19,75 \%)$, contract logistics - 3PL $(16,61 \%)$, retail $(11,6 \%)$ and other industries $(8,5 \%)$. When regarding the size of the company, most of the respondents are employed in companies with over 1000 employees (34,2\%), followed by companies with 150-300 employees (27,6\%). The smallest number of respondents are employed in companies with 600-1000 employees. From the aspect of the position of the respondents, three groups are dominant: Logistics Manager (18\%), Transport Manager (17\%) and Logistics Assistant (13\%). Answers to question related to the years of work experience of the respondents showed that over $60 \%$ of the respondents have $3-7$ years $(35,1 \%)$ or $7-15$ years $(31 \%)$ of working experience.

\subsection{Recruitment and Retention of the Logistics Workforce in Serbia}

Questions from the second group were intended to examine the recruitment, retention and fluctuation of labor in logistics. When it comes to employment, almost half of the respondents $(49,5 \%)$ did not wait for the first job, around 31\% waited up to 6 months, while the rest waited over 6 months (figure 3). When it comes to fluctuation, then the results show that he vast majority of respondents generally worked in 1-5 companies (as much as $95,9 \%$ ), while the remaining 4,1\% worked in over 6 companies. On the basis of the results of this question, it can be concluded that the majority of respondents worked in 3-5 companies (37\%). For over half of the respondents, the period of 1-5 years is the average time spent in one company, with a dominant period of $1-3$ years $(37,6 \%$ of respondents).

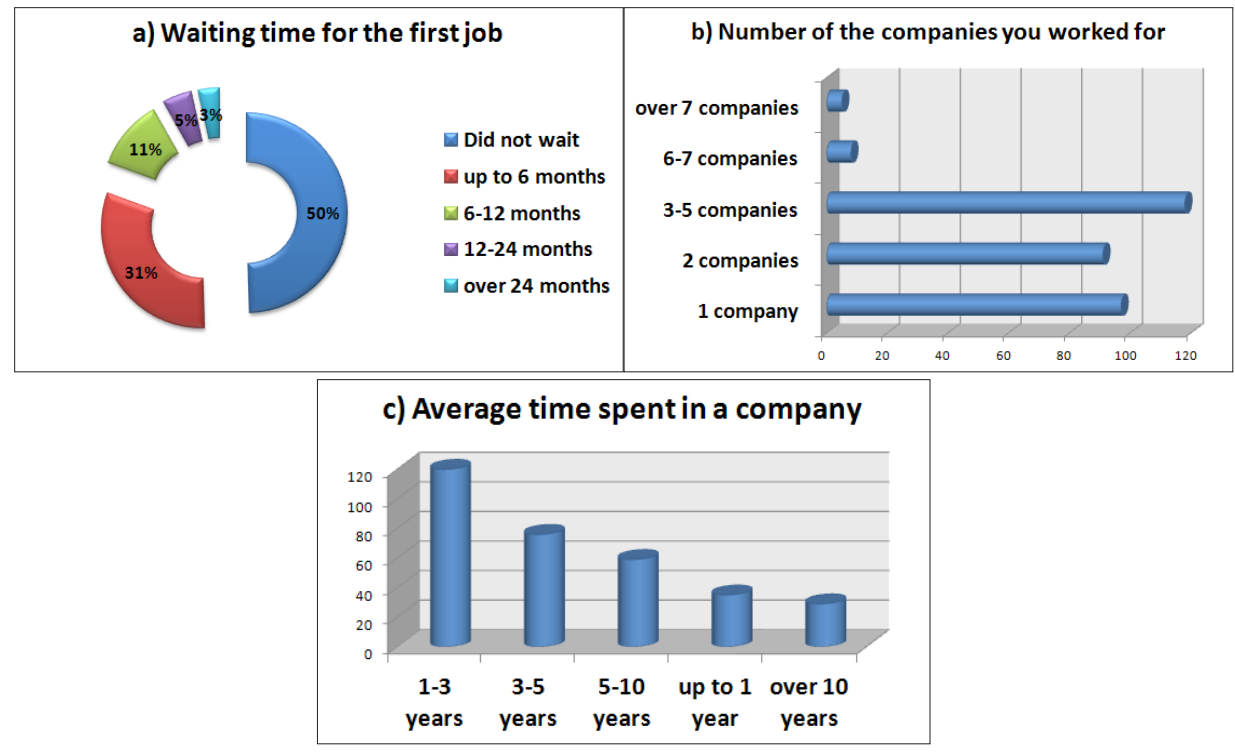

Fig. 2.

Recruitment and Retention of Logistics Personnel in the Serbian Market 
These results show the high demand for logistics workforce in Serbia. These facts are confirmed by the official data of Infostud, the most famous advertising portal for jobs on the Serbian market. According to these data, it was established that in 2018 there were 829 ads related to management positions in the field of logistics (logistics managers, referents and dispatchers), which is 2,2 ads each day. In addition, there were 1455 ads for warehouse operations, forklift trucks and 1521 ads for transport workers (drivers, couriers, etc.). When it comes to estimating the annual growth in demand for logistics experts, the majority of respondents (over 65\%) said that in the coming years the growth rate would be $3-10 \%$.

In addition to fluctuations between companies, the survey examined the movement of staff within a company (figure 3). Over half of the respondents indicated that they changed 1-2 positions $(63,64 \%)$, where most of them remained in one position for about 2 years $(54,9 \%)$ and $2-5$ years $(35,1 \%$ of respondents). The main reasons for changing the company were the impossibility of promotion (49,22\%). Beside this, second reason is related to the salary $(44,83 \%)$. Two reasons that were present in less than 100 respondents, but which are still significant are lack of vision $(29,15 \%)$ and poor interpersonal relationships $(27,27 \%)$. When considering the average salary, given that this question was not mandatory, 294 respondents answered. Out of the total number of respondents, two dominant answers were singled out: from $700-1000 €(28,9 \%$ of respondents $)$ and 1000-2000 (27,6\%). The smallest number of respondents has a salary over $3000 €$ (only $3,4 \%$ ).

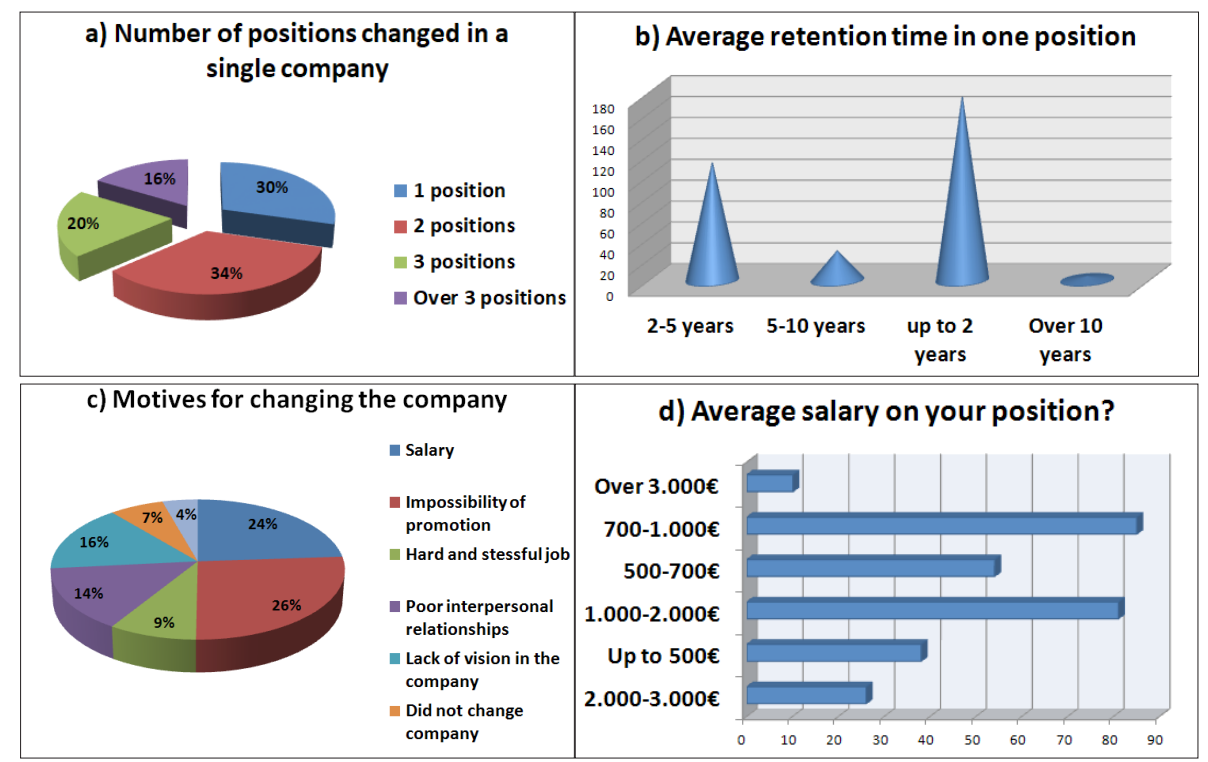

Fig. 3.

Fluctuation of the Workforce in Logistics Sector 


\subsection{Education and Competencies of the Logistics Workforce}

The next group of questions concerned the establishment of education and the necessary skills of logistics workforce in Serbia. Of the total number of employees in logistics $66,8 \%$ of the respondents graduated from the Faculty of Transport and Traffic Engineering, of which $42,6 \%$ Department for logistics, followed by the Faculty of Economics (8,5\%), Faculty of Technical Sciences Novi Sad (7,2\%), Faculty of Organizational Sciences $(5,3 \%)$ and other faculties and schools $(15,4 \%)$. Only Faculty of Transport and Traffic Engineering, Logistics Department, educates logistics workforce with all the competencies in logistics and supply chains, while other faculties mainly focus on other competencies and have a few logistics subjects. In order to determine how much companies invest in employee development, a question regarding the number of external or internal trainings that the respondents went through in their careers were asked. It was found that the vast majority of $81,5 \%$ of the respondents had between two and more than five trainings, while the rest of $18,5 \%$ did not have any form of training.

When it comes to the knowledge necessary for successful job performance, the majority of respondents stated that professional logistics knowledge, business communications, foreign language, management and organizations are crucial (figure 4).

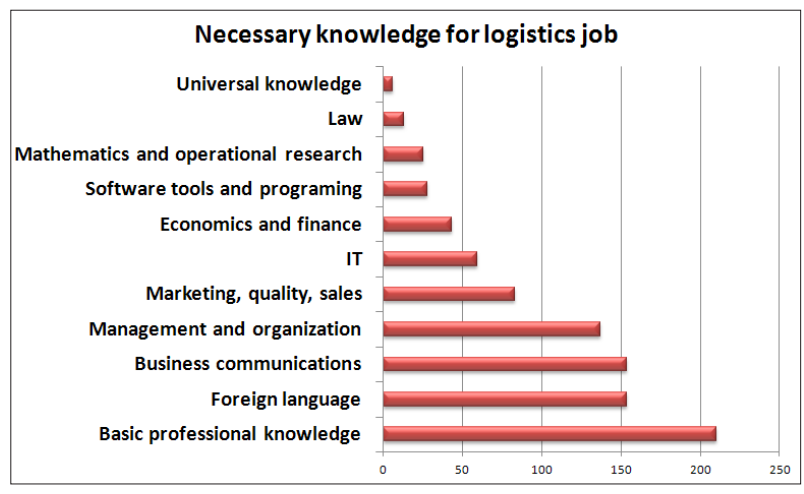

\begin{tabular}{|c|c|}
\hline Which competencies are expected from students when they graduate & Number of respondents (\%) \\
\hline Interest and motivation for work & 82.8 \\
\hline Knowledge of basic computer programs & 80.6 \\
\hline Knowledge of foreign language & 80.3 \\
\hline Personal qualities & 74.9 \\
\hline Communication skills & 64.9 \\
\hline Practical skills & 47.6 \\
\hline Professional knowledge & 43.6 \\
\hline Other & 5.3 \\
\hline
\end{tabular}

Fig. 4.

Necessary Competencies of Logistics Workforce 
When respondents were asked about what would, in their opinion, contribute to the improvement of the competencies of logistics experts, the majority of respondents mentioned the innovation of curricula $(74,3 \%)$, better cooperation between faculties and companies $(67,7 \%)$ and internal and/or external employee training (51,7\%). The main characteristics and competences expected from student when they finish their studies are interest and motivation for work, knowledge of computer programs, foreign language skills, personal qualities (team work, behavior, etc.) and communication skills. The views on professional practice were examined where paid scholarship emerged as a dominant way of organizing the practice, which was chosen by $74,3 \%$ of the respondents, followed by mentor's work $(67,7 \%)$ and defined practice program $(51,7 \%)$. From the aspect of the duration of the practice, dominant responses relate to full-time work for 3-6 months a year (37,3\%) and full-time work for up to 3 months a year $(28,2 \%)$.

\section{Conclusion}

Based on the analysis carried out, it can be concluded that there is an evident lack of labor in the world with the necessary logistics competencies and skills. In addition to significant workforce potential, this problem has been seen in the Serbian market in recent years. This is due to two key causes. The first refers to increased economic activity and the arrival of foreign companies that generate more and more demands for logistics. The annual needs for logistics workforce largely exceed the number of trained personnel. Another problem is the openness of the market and the departure of human resources abroad, especially the EU countries, where wages are significantly higher and working and living conditions are better. In addition to the insufficient number of young educated staff, the problem also arises with the existing workforce that is not adequately educated and has no competencies that require new technologies and modern ways of doing business. In certain positions in logistics, personnel do not have appropriate formal logistics education or the necessary logistics skills. The potential for employment in logistics is limited by the low reputation and status of this sector in the economy and society. This does not attract young enough when choosing a career. It is necessary to improve the image and position of logistics activity. The nature of work, working conditions and advancement, low wages and low social status are just some of the reasons for insufficient interest in the logistics profession.

Solutions for the successful development of this extremely important profession must be sought through the close collaboration of business companies, educational institutions and the public sector. These are three key parties that make up a triangle in which a synergistic effect can be achieved which will result in a greater number of experts with appropriate logistics competencies and skills. Businesses must make more efforts to create conditions, work environment and ambience to attract labor, but also to work on career guidance and advancement, external and internal training, and greater motivation for the employed. Universities and other education institutions need to adapt their curriculum to the real needs of the market as much as possible and to enrich the theoretical and systematic knowledge with more practical skills. The public sector and the competent state institutions must pay more attention to the creation and development of logistics staff, through concrete support to 
formal and non-formal education. In addition to investing in infrastructure and regulation, it is necessary that the state invest more in the education and development of human resources in logistics and supply chains. In future researches, it is necessary to increase the sample, as well as to determine the degree of correlation between certain factors.

\section{Acknowledgements}

This paper was supported by the Ministry of Education, Science and Technological Development of the Republic of Serbia, through the project TR 36006.

\section{References}

Andrejić, M.; Bojović, N.; Kilibarda, M. 2013. Benchmarking distribution centres using Principal Component Analysis and Data Envelopment Analysis: a case study of Serbia, Expert Systems with applications 40(10): 3926-3933.

Cottrill, K.; Rice Jr. J.B. 2012. Supply Chain Talent Management: Addressing the HR Disconnect. MIT Center for Transportation \& Logistics White Paper (Winter): $1-16$.

Ellinger, A. E.; Ellinger, A. D. 2014. Leveraging Human Resource Development Expertise to Improve Supply Chain Managers' Skills and Competencies, European Journal of Training and Development 38(1/2): 118-35.

Fisher, S. L.; Graham, M. E.; Vachon, S.; Vereecke, A. 2010. Guest Editors' Note: Don't Miss the Boat: Research on HRM and Supply Chains, Human Resources Management 49(5): 813-828.

Harvey, M.G.; Richey, R.G. 2001. Global Supply Chain Management: The Selection of Globally Competent Managers, Journal of International Management 7: 105-28.
Hoberg, K.; Alicke, K.; Flothmann, C.; Lundin, J. 2014. The DNA of Supply Chain Executives. Supply Chain Management Review (November): 36-43.

Hohenstein, N. O.; Feisel, E.; Hartmann, E. 2014. Human Resources Management Issues in Supply Chain Management Research: A Systematic Literature Review from 1998 to 2014, International Journal of Physical Distribution \& Logistics Management 44(6): 434-463.

Kilibarda, M.; Nikoličić, S.; Andrejić, M. 2016. Measurement of logistics service quality in freight forwarding companies: a case study of the Serbian market, The International Journal of Logistics Management 27(3): 770-794.

McKinnon, A.; Flothmann, C.; Hoberg, K.; Busch, C. 2017. Logistics Competencies, Skills, and Training: A Global Overview. A World Bank Study. Available from internet: <https://openknowledge.worldbank.org/ handle/10986/27723>.

Richey, R. G.; Tokman, R.; Wheeler, A. R. 2006. A Supply Chain Manager Selection Methodology: Empirical Test and Suggested Application, Journal of Business Logistics 27(2): 163-190.

Sheffi, Y. 2013. Logistics-Intensive Clusters: Global Competitiveness and Regional Growth. In Handbook of Global Logistics, 463-500. New York: Springer Science + Business Media.

Slusarczyk, B.; Kot, S. 2011. Logistics Education as a Way for Unemployment Reduction. In Proceedings of the IETEC'11 Conference, Kuala Lumpur, Malaysia.

Thai, V. V. 2012. Competency requirements for professionals in logistics and supply chain management, International Journal of Logistics Research and Applications 15(2): 109-126.

\section{jitte 279}

